\title{
ARTICLE
}
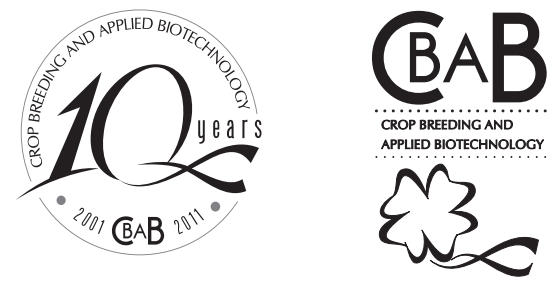

\section{Evolution of plant breeding}

\author{
Arnel R. Hallauer ${ }^{1 *}$ \\ Received 1 August 2011 \\ Accepted 20 August 2011
}

\begin{abstract}
Plant breeding is considered one of the longest ongoing activities undertaken by humans, who select plants more productive and useful to themselves and the animals for at least 10,000 years ago. The evolution of civilizations paralleled the success of plant breeding, although this has not been recognized by the public. The reason may be lack of understanding of what plant breeding encompasses. The concept of plant breeding evolved, depending on the time it was formulated, but without losing the essence of being art and science of manipulating plants for man. This review discusses the evolution of the concepts and the methods of plant breeding, here divided arbitrarily into selection based on phenotypes, breeding values and genotypes. No matter how big the pool of genetic information in recent years, the phenotype will continues to be important in the present and future.
\end{abstract}

Key words: concepts of plant breeding, phenotypes, breeding values, genotypes.

\section{INTRODUCTION}

Plant breeding has to be considered one of the longest, continuous activities conducted by humans. The evolution of the human civilizations paralleled the successes of plant breeding. Although we would consider the early plant breeding methods rather simple compared with present-day methods, the transition from a nomadic life style of the hunter gathers to sedentary life styles that required adequate supplies of food, feed, fuel, and fiber to sustain sedentary-type cultures depended on individuals to identify and to improve plants that met their needs. The transition of life styles was due to the availability to plant resources to sustain human and livestock needs. It has been estimated that the dawn of human civilizations was approximately 10,000 years ago. Hence, it would be a reasonable assumption that plant breeding activities were taking place at least 10,000 years ago, selecting plant types that were most productive and useful to provide for the human and animal needs.

The initial plant efforts were necessary for survival of the human civilizations because they developed improved cultivars that were more productive, and, in some instances, depended on humans for their survival (e.g. maize, Zea mays L.). The early plant breeders were effective in developing productive cultivated plant species from wild species that were lower in productivity but possessed many important traits for their survival in the wild; even today, plant breeders occasionally seek for important traits (e.g., pest resistance and drought tolerance) from the progenitors of our cultivated crop species. Adaptation was the main trait used in selection, which was based on the model, or ideal, of the breeder.

Although plant breeding had a significant role in the development of different human civilizations, plant breeding is generally not recognized as a major activity by

\footnotetext{
${ }^{1}$ Iowa State University, Ames, IA 50011, USA. *E-mail: hallauer@iastate.edu
} 
the general public. Developments made in medicine, engineering, electronics, transportation, space travel, etc have received greater attention that plant breeding. But if greater energy had to be allocated to developing adequate food supplies, progress in the other human activities would have to be more limited. For example, less than $2 \%$ of the population of the United States is involved in agricultural crop production which provides adequate quantities of different crop species to meet the food, feed, fiber, and fuel needs of the remainder of the population. Hence, energy and resources can be directed to other activities (e.g., medical and space research) that can be of benefit to society.

One of the problems, perhaps, for why plant breeding has received limited recognition and credit, is because there is not a general understanding of what plant breeding encompasses. Even within the plant breeding discipline, there are some differences as to what defines plant breeding. Several authors have offered what they considered were the objectives of plant breeding. Some examples: breeding is the evolution by the will of man (Vavilov 1935); plant breeding is the genetic adjustment of plants to the service of man (Frankel 1958); plant breeding is a unique science in at least two ways. First it uses knowledge and techniques from many basic science areas, and second its contributions to agricultural progress are measured not only by information, but also by material products, such as crop varieties, hybrids, clones, etc. (Frey 1966); the breeding of plants and animals is a form of evolution, dependent in large part upon the same rules that regulate the evolution of natural selection (Briggs and Knowles 1967). The breeding of plants and animals is an exercise in exploiting the genetic system (Williams 1964); plant breeding can be defined as the application of techniques for exploiting the genetic potential of plants (Stoskopf et al.1993); plant breeding is the art and science of improving humankind (Poehlman and Sleper 1995); plant breeding is the science, art, and business of improving plants for human benefit (Bernardo 2002); and plant breeding is the art and science of improving the genetic pattern of plants relation to their economic uses.

Although there are differences among authors for the objectives of plant breeding, one common theme is that plant breeding includes the art and science for manipulating genetic systems to develop superior cultivars. The changes in emphasis are because of the time-frames when the objectives of plant breeding are discussed. These objectives range from plant evolution manipulated by human's conscious selection (Vavilov 1935) to development of proprietary cultivars in a highly competitive industry (Bernardo 2002). The relative importance of art vs. science in plant breeding also has changed dramatically during the past 100 years with greater emphasis on science. There have been several important stages during the history of planting beginning with the domestication of wild species approximately 10,000 years ago. For purposes of discussion in the evolution of plant breeding methods, I have arbitrarily partitioned them based on the primary methods of selection and the information available to plant breeders; selection based on phenotypes, breeding values, and genotypes. These are not distinct stages because there are different time periods for each of the three stages and each overlaps with others. Each stage however, has been very important although the time frames are very different.

\section{PHENOTYPES}

Phenotypes result from the combination of genetic and environmental effects of individuals. Phenotypes are the visual trait(s) observed and are the first features that are obvious whether expressed as a beautiful ornamental flower, maturity, plant stature, resistance to pests, or any other observable trait. Phenotypes of individuals were obviously the unit of selection by the earlier plant breeders because selection based as phenotypes (usually referred to as mass selection) was the obvious method of selecting for the desired types. Initially, selection was for the more productive phenotypes among the wild, weedy plants species to provide adequate quantities of food for the primitive civilizations. Gradually, the range of traits considered in selection was expanded to include better adaptation, preferred plant and seed types, greater resistance to pests, and other traits considered for decorative and ceremonial purposes.

Phenotypic selection is certainly the plant selection method with the longest, continuous use in plant improvement. It is a simple method that requires minimum resources and has been an effective method in many instances. The greatest contributions from phenotypic selection have to include making the transition from the wild, weedy plant species to cultivated crop species. In most instances, it probably included making small, incremental changes that, with a few useful mutants, eventually led to crop species dependent on humans for their survival. Progress was not a smooth positive trend, but included hundreds of generations of selection with 
cumulative effects that were usually in the desired direction. Because the effectiveness of phenotypic selection depends on the relative heritabilities of the traits, greater progress naturally was made for traits with the greater heritabilities. The effects of phenotypic selection can be illustrated with the history for the development of cultivated maize (Zea mays L.). Present evidence suggests that modern maize was developed 7,000 to 10,000 years ago in the highlands of southern Mexico and northern Guatemala; species of teosinte are the presumed parental material which can survive in the wild. The transition from grassy-type plants with small seeds easily distributed for survival in the wild to the modern-day plant with kernels attached to large cobs that required hundreds of generations of selection. By the time Columbus arrived in the Western Hemisphere in 1492, Native Americans were growing adapted maize cultivars throughout the Western Hemisphere. Selection was successful in developing, cultivars for many different environmental niches throughout the Western Hemisphere. The long term effects of phenotypic selection developed a productive crop species that contributed immensely to the different civilizations distributed throughout the Western Hemisphere.

Sturtevant (1899) reported that there were 189 distinct maize cultivars in the United States at the end of the $19^{\text {th }}$ century. The varieties were developed by selecting phenotypes that were adapted to different maturities (23 to 42 degrees north latitude), adapted to different soil types, specific plant and ear types, and specific kernel types and colors. Phenotypic selection developed maize cultivars that were visually distinctive for each of the geographic areas of the United States. Some of the cultivars (e.g., Reid Yellow Dent) became widely known because of prizes won at local and national maize shows and became widely used because they were presumed to be superior to other varieties. But the development of distinctive cultivars did not contribute to greater grain productivity. If one examines the average U.S. maize yields from 1865 to 1935 , average grain yields exceeded 1.88 tons ha ${ }^{-1}$ (30 bu acre $\left.^{-1}\right)$ in only 4 years $(1896,1905,1906$, and 1920) during the 70-year span. Phenotypic selection, therefore, was very effective for many traits but not for grain production.

It has been shown that phenotypic selection is effective for traits that have relatively simpler genetic systems; i.e., have higher heritability (Hallauer et al. 2010). Because phenotypic selection is based on selection among individuals, the combination of genetic and environmental effects cannot be separated. The variance among phenotypes
$(\mathrm{Vp})$ depends on the genetic variance $(\mathrm{Vg})$ and the environmental variance (Ve) and the heritability $(\mathrm{H})$ can be expressed as $\mathrm{Vg} / \mathrm{Ve}$. If the environmental effects are relatively small (e.g., maturity and kernel color), phenotypic selection is more effective than for grain yield, a more complex trait genetically that is affected by environmental effects throughout the growing season. Although phenotypic selection has been used for thousands of years, there is continued interest in the method. Gardner (1961), Abreu et al. (2010), and MarquezSanchez (2010), for example, have made suggestions to increase effectiveness of phenotypic selection primarily to reduce the environmental effects on selection.

Phenotypic selection is commonly used in plant breeding programs and the results are similar to those experienced in developing the open-pollinated cultivars. Bauman (1981) summarized the responses of 130 maize breeders located within the U.S. Corn Belt to questions related to the development of inbred lines and hybrids. Bauman desired information as to how effective phenotypic selection was among and within inbred lines during inbreeding. Bauman included 17 plant and ear traits and asked the breeders to rank the traits for their relative importance and how effective phenotypic selection was for each trait (Table 1). Grain yield and stalk strength (1.2) had the highest rankings for importance, but the effectiveness of phenotypic selection was considered lowest for grain yield (3.2) and stalk strength (2.5). Traits that ranked the highest for effectiveness of selection included flowering date (1.3), plant and ear height (1.5) and plant color (1.5), all of which tended to be ranked as less important. There tended to be negative association $(r=0.544)$ between the relative importance of the traits and the effectiveness of phenotypic selection.

Phenotypic selection has the longest history of any plant improvement method; it was used to develop cultivated crop species from their wild, weedy punitive parent species and continues to have use in germplasm development and breeding nurseries. Phenotypic selection obviously has been very important in developing our current germplasm resources and probably has to be considered one of plant breeding's greatest accomplishments. And phenotypic selection will always have a place in plant breeding, but its effectiveness will depend on the traits considered in selection and minimizing environmental effects (Hallauer and Carena 2009). There continues to be theoretical interest as to what variables can be controlled to increase its effectiveness (Abreu et al. 2010, Marquez-Sanchez 2010). 
AR Hallauer

Table 1. Summary of the responses from 130 maize breeders in the U.S. Corn Belt on how effective phenotypic selection was for 17 plant and ear traits

\begin{tabular}{lcc}
\hline Traits & Importance of trait & Effectiveness of selection \\
\hline Grain yield & 1.2 & 3.2 \\
Stalk strength & 1.2 & 2.5 \\
Root strength & 1.4 & 2.6 \\
Stalk rots & 1.5 & 2.3 \\
Silk emergence & 1.6 & 1.4 \\
Leaf blights & 1.7 & 1.6 \\
Ear rots & 1.8 & 2.1 \\
Seedling vigor & 1.9 & 1.9 \\
Flowering date & 1.9 & 1.3 \\
Tassel and pollen shed & 1.9 & 1.7 \\
Resistance to insects & 2.0 & 2.7 \\
Kernel quality & 2.1 & 1.9 \\
Plant and ear height & 2.2 & 1.5 \\
Resistance to Ustilago maydis & 2.3 & 2.2 \\
General plant appearance & 2.3 & 1.8 \\
Leaf orientation - erect & 3.0 & 1.6 \\
Plant color & 3.2 & 1.5 \\
\hline Correlation & 0.544 & \\
\hline
\end{tabular}

Source: Bauman (1981). Rankings (1-4); 1 is most important or good and 4 is not as important or poor.

\section{BREEDING VALUES}

The rediscovery of Mendel's laws of genetics in 1900 and the concept of natural selection by Darwin (1859) provided the foundations of modern plant breeding. During the 150 years previous to the rediscovery of Mendelism in 1900, plant biologists had been studying hybrids produced from parents having distinct phenotypes and the recovery of parental phenotypes in the F2 and backcross generations. Because the principles of inheritance were not understood, various explanations were offered for the phenotypes observed in the crosses and their segregating populations, depending, of course, on the traits measured and the species under study. In most instances the biologist's primary interests were not directed at plant improvement or cultivar development, but to gather basic information on the inheritance of traits and how they were sexually transmitted from parents to their offspring. Dunn (1965), however, considers Kolreuter one of the founders of modern studies of sex in plants and of scientific plant breeding. Kolreuter was one of the earlier hybridizers and made significant biological contributions to the study of sex in plants but I would not include him as one of the founders of modern plant breeding. Some of the earlier hybridizers made detailed studies of hybrids and their segregating generations, but none, as did Gregor Mendel, could develop a definitive theory for the transmission of traits from parents to their offspring. This failure caused different theories for the inheritance of traits but, in most instances, the suggested patterns of inheritance were not too appealing and/or satisfactory for those suggesting them, including Darwin when developing his theory of natural selection. It was unfortunate that Darwin was not aware of Mendel's principles of inheritance, reported in 1865. Darwin and Mendel were contemporaries, and if Darwin had knowledge of Mendel's laws of inheritance it would have been extremely interesting how the information from Mendel's research would have impacted Darwin's thinking in developing his theory of natural selection. Amalgamation of Darwins and Mendel's research was not to be realized until nearly 50 years after Mendel reported his genetic studies with the garden pea (Pisum sativa) (Provine 1971).

Mendel's research was not available to plant breeders and biologists during the $19^{\text {th }}$ century, and phenotypic selection was emphasized in both adapted and unadapted landrace cultivars. Because of the range of genetic variability available in the landrace cultivars, selection was effective for many traits and less effective for other traits, such as yield and quality. But there were individuals who considered that selection based on the progenies of individuals would be more effective than on the individuals themselves. Vilmorin in France was the first to suggest 
and use the progeny test in 1859 for the improvement of size, shape, and sugar content of sugar beets (Coons 1936). How widely Vilmorin's suggestion was used the latter part of the $19^{\text {th }}$ century is not known but Hopkins (1899) used a similar procedure, later designated as ear-to-row selection, to change the chemical composition of maize grain. Although the progeny test or ear-to-row methods were suggested prior to an understanding of Mendelism, these methods continue to have use, also with the modifications to increase the effectiveness of the progeny test methods (e.g., Lonnquist 1964).

The rediscovery of Mendelism and Darwin's theory of natural selection certainly provided the genetic basis for plant improvement but other concepts developed during the first 30 years of the $20^{\text {th }}$ century also had major impacts on developing breeding methods for plant improvement. The concepts were quite different in origin but they were integrated with Mendelism and Darwin's theory of natural selection and contributed to a greater understanding of the heritability of the different traits considered in selection and how proper experimental methods can be used to determine the relative importance of the genetic and environmental effects on trait expression and ultimately the breeding values of individuals. The importance of proper experimental design and statistical analyses is appreciated by all plant breeders to determine the quality of their data for making effective selection. Since the introductions of the concepts of experimental design and statistical analyses by Fisher (1925), researchers have continued to enhance and refine the concepts of experimental design and statistical analyses to reduce experimental error in order to increase the precision of our estimates of breeding values. After the rediscovery of Mendelism, it was soon found that the inheritance of our more important economical traits were not as simple as some of traits studied by Mendel, Bateson, Devires, etc (Provine 1971). Different methods of analyses were needed to study the cumulative effects of a larger number of genes in trait expression. During the first half of the $20^{\text {th }}$ century, there were two separate, but not distinct, areas of genetic studies: 1) more classical genetics to study segregation and gene expression for many major genes, and 2) areas of genetics designated as quantitative genetics, biometrical genetics, and population genetics to study allele frequencies and their effects for the inheritance of complex traits. Although classical genetics have been very informative in learning how genes segregate and express themselves, knowledge of the inheritance of quantitative traits has had greater impact and direction on developing and conducting plant breeding strategies. Mendel's analyses of his genetic studies clearly showed that parents pass genes and not their genotypes to their progeny. During the period from 1900 to 1930, plant breeders were very active in genetic studies, particularly for traits that could be classified on the basis of the progeny's phenotype (Dunn 1965). But many of the traits (e.g., productivity) that were of interest to plant breeders were not amenable to Mendelian analyses. Fisher (1918) formulated concepts and analyses that established a frame work for the study of the more complex traits. He found that the average effects of the parent's alleles determined the genotypic value of its progeny; i.e., the additive effects were transmitted from parents to their offspring. The breeding values of the parents could be determined by the mean value of its progeny as a deviation of the progeny from the population mean (Falconer 1960). The study of the inheritance of complex traits (i.e., quantitative genetics) was accomplished by integrating the concepts of Mendel and Darwin, which became the foundation of plant breeding for the past 110 years. A basis was established for inheritance of quantitative traits and the concepts of natural selection were used except direction of selection was controlled by plant breeders in the desired directions.

For plant breeders to be proficient in identifying superior cultivars, they have to accurately determine the relative breeding values of the progenies that are being evaluated. This principle is equally valid in basic research studies to determine the relative importance of genetic effects (additive and nonadditive) of progenies in recurrent selection studies, and in applied breeding programs evaluating progenies developed from $\mathrm{F}_{2}$ populations of elite line crosses. Hence, good experimental plot techniques are very important to make valid comparisons. Fisher (1925) developed the concepts of randomization, replication, and repeatability (experiments repeated across environments) to separate and estimate the relative importance of genetic effects, environmental effects, and experimental error. The Anova provides a tabular form of the analyses of progeny data collected over replications and environments. From the Anova, one can estimate of components of variance for experimental error, genotypic variability, and environmental variability, which can be used to estimate heritability and predict genetic response to further selection (predicted $=\mathrm{DH}$, where $\mathrm{D}$ is selection differential and $\mathrm{H}$ is heritability). Plant breeding was probably the first important discipline to use and realize the importance 
of good experimental data and to determine estimates of experimental error to statistically determine if differences among progenies are significant. Valid comparisons between progenies are essential if plant breeders are successful to develop genetically superior cultivars compared with those currently grown. Plant breeders have always eagerly accepted newer suggestions offered in experimental designs (e.g., Latin squares, lattices, alpha, beta, etc.) and analyses (e.g., stability analyses) to increase their effectiveness of identifying superior genotypes.

One other item that has impacted and stimulated extensive plant research during the $20^{\text {th }}$ century was the suggestion of use hybrids as crop cultivars, particularly in cross-pollinating crop species. Shull (1910) elegantly described the concept for producing maize hybrids: develop inbred lines vie self-pollination; produce F1 crosses between inbred lines; evaluate F1 crosses to determine the relative yield of the crosses; and select the best cross for distribution to the producers. Initial response to the inbred-hybrid concept was slow, but during the 1930's and 1940's the inbred-hybrid concept was extensively tested and hybrids rapidly accepted by the producers. Today, nearly all the maize cultivars grown in major production areas are hybrids. The interest in hybrids also stimulated tremendous interest in the genetic basis of heterosis and how genetic systems can be enhanced to increase the expression of heterosis (Coors and Pandey 1999, Tracy and Chandler 2006, Pixley 2006). Since the concept of hybrid maize was introduced by Shull (1910) it has been tested and commercially used in other plant species (Coors and Pandey 1999).

The concept of determining the breeding values of parents vie progeny testing was one of the major factors for productivity advances made during the $20^{\text {th }}$ century. Most studies suggest that 50 to $60 \%$ of the advances made in maize grain yields were because genetic improvements made in the inbred lines and hybrids (Tollenaar 1989, Eyerhabide and Damilano 2001, Duvick 2004). Although not as great in other crop species, significant advances have been made for productivity and tolerance to pests, drought, acid soils, etc (Frey 1996). Breeding values will continue to be an important component in future plant breeding programs in choice of parents considered in developing breeding populations.

\section{GENOTYPES}

Indirectly, genotypes have always been the basic unit of selection, whether by either natural or human selection. During the millennia that included domestication, phenotypic selection, evaluation of breeding values, and presently when molecular genetics are employed in the choice of parental genotypes, and development of genetically modified organisms (GMO's) the genotypes of individuals remains the unit of selection. How effective genotypic selection is depends, of course, on the heritability of the trait, which is determined by how the environment affects genotype expression. During the early part of the $20^{\text {th }}$ century, plant breeders and geneticist were able to study and map locations on the chromosomes for mutant genes that could be classified on the basis of their segregation of their phenotypes. These traits were considered to be Mendelian type traits in their inheritance and included endosperm types, leaf orientation, awns vs awnless, plant size, ear shape, etc. These genetic studies were informative for determination of chromosome organization, but they did not contribute directly to developing new cultivars. The kernel mutants of opaque and floury in maize are an example. Both mutants enhanced protein levels and protein quality, but the correlated effects of lower yield, poorer grain quality for harvest, storage and transport, greater grain moisture, and greater susceptibility to plant and ear pests negated the advantages of protein levels and quality. It was only by long-term breeding programs that the negative effects of the opaque and floury mutants were overcome to develop useful inbred lines and hybrids (Vassel 2001). In nearly all instances major mutant alleles have had a negative impact on productivity, and it was only after major breeding efforts were conducted that useable products were developed that included the mutant allele (Hallauer 2001). The experiences with mutant alleles that have major effects on specific traits usually have not had a major impact on plant breeding: mutant alleles have generally had deleterious effects on other important economic traits; and it was not until plant breeders were able to select for other modifying alleles to reduce the deleterious effects of the mutant alleles did they have some use. Successful breeding methods, therefore, depended on genes and alleles that have consistent performance across the target environments. Although the use of major mutant alleles have had minimum impact on cultivar development, genetic studies were very useful for developing the chromosome arrangement of genes for most major crop plant species. But the gene and chromosome structure and their chemical composition were not known. Geneticists and chemists had determined that genes produced specific proteins, but the nature of the gene and how specific 
proteins were produced were intensively studied the latter part of the $20^{\text {th }}$ century.

Similar to the rediscovery of Mendel's laws of inheritance in 1900, a significant change in the study of genetics occurred when Watson and Crick (1953) reported on the structure and chemical composition of the hereditary materials by Watson in 1968. Extensive studies by geneticists and plant breeders from 1900-1930 had verified the particulate nature for the segregation of alleles and used the same principles for the study the inheritance of quantitative traits. With the combination of Mendelian genetics, Darwin's concepts of natural selection, development of experimental design and statistical analyses, plant breeders had made significant progress in developing and implementing breeding systems to develop genetically improved cultivars by 1950 . There was nearly a 50 -year lag time until all the different sources of genetic information were integrated for effective use by plant breeders during the decades of 1930-1950. Another factor that stimulated extensive theoretical and basic research was the inbredhybrid concept, which by 1950 double-cross hybrids was planted, on nearly $100 \%$ of the maize production areas of the United States. Although there were vigorous and extensive genetic studies, the basic unit of selection was at the phenotypic level. Selection at the phenotypic level based on breeding values became more effective because experimental design and statistical analyses permitted the estimation of the relative importance of the environmental and genetic effects (i.e., inheritance) and the breeding values of the parents. Extensive phenotypic data were collected and analyzed, based on replicated progeny trials repeated across the target environments (locations and years).

A similar pattern has evolved since the report by Watson and Crick (1953). Extensive genetic studies were conducted at the molecular level to determine gene organization, functions, products, transmission, etc., but there was one difference. After the rediscovery of Mendelism in 1900, plant breeders were actively involved in the genetic studies, both independently and in combination with geneticists. For the detailed molecular genetic studies, the techniques and knowledge required were usually not available to plant breeders. Because of potential predicted by the molecular geneticists from the detailed information derived at the molecular level, plant breeders played a minor role in the genetic studies. Whereas support for plant breeding had rapidly increased (particularly after WWII) with the understanding of Mendelian genetics, direct support in many instances decreased, both in financial support and positions: the funds and personnel positions were diverted to support the expensive molecular genetic research. It was not realized until later, that if the benefits of the information derived from molecular genetic studies were to be utilized, that plant breeding became a necessary component of the matrix for the potential use of information and products derived from the molecular genetics.

Initially, and similar to the early studies of Mendel's laws of inheritance, the molecular geneticists focused on a few genes that had major effects. It seems, however, that the insertion of specific DNA segments into plant's genome and their desired expression was more difficult than originally envisioned. Progress, however, was eventually realized for traits that contributed either resistance or tolerance to some of the important pests for maize production. Some examples include resistance to specific herbicides for weed control and to infestations by specific groups of insects. Both of these traits have had widespread use for some of the major crop species (Gepts 2002). Similar to Mendelian genetic studies, the molecular geneticists also realized that if molecular genetics were to contribute to the long-term improvement of crop species that they needed to focus on the improvement of quantitative traits. The inheritance of quantitative traits at the molecular level was as difficult as the Mendelian geneticists confronted 100 years ago. But with the sequencing of the genomes of major crop species, improved techniques to identify genes, and reduction in costs, theory and experimental data have been suggested and used to identify quantitative traits loci (QTL's) and to incorporate the information in breeding and selection programs (Johnson 2004). Molecular genetics will continue to impact plant breeding and selection. A new generation of plant breeders with education and training in molecular genetics will have greater participation in the breeding methods, particularly for the improvement of complex traits. Marker assisted selection (MAS) will enhance selection for more complex traits (e.g., yield, drought tolerance, tolerance to acid soils, disease resistance, quality, etc), but the one major difficulty will be the resolution of gene interactions and their interactions with environments; these are the same problems that have impacted plant breeding throughout its long history. Information from molecular genetics has enhanced plant breeding by identifying the appropriate parents to include in breeding crosses, assignment of genotypes to appropriate heterotic groups, and major alleles that will enhance 
selection for complex traits. The volume of genetic information to the plant breeder is several times greater than in the past. Computer software and hardware advances have made possible the greater incorporation of genetic information that can be used in selection. The increased information available has dramatically increased the relative importance of science, compared with art, in plant breeding. Although plant breeders have greater genetic information compared with 50, 100, or 1,000 years ago, the plant phenotypes are still an important, and will remain so in the future (Lee 2006).

\section{FUTURE}

Plant breeding efforts, starting with the domestication of wild plant species to the present, have played a significant (although generally unrecognized) role in providing the food, feed, fuel, and fiber needs for the development of human civilizations to sustaining more than 6 billion humans presently living in the world. We need to sustain these efforts if the predicted 9 billion humans are inhabiting the earth by 2050 or nearly $37 \%$ more inhabitants in 2050 , compared with 2010. From the time of Malthus at the start of the $19^{\text {th }}$ century, there have been some who have predicted that the rate of growth of the human population would overwhelm their ability to provide for their food needs. The landscape for plant breeding has changed dramatically even during the past 100 years. Yields of our major crop species have gradually increased during the past 100 years. Genetic information has increased exponentionally during the past 30 years and will enhance selection at the phenotype level. The world has a finite land area for crop production. The increases in crop yields have sustained human needs, particularly for food. In most instances, crop yields on a per unit basis have increased during the past century (Frey 1996). Because of political situations, infrastructures, and distribution problems, millions of humans today still do not have either adequate or nutritional diets to sustain healthy lives, but in several cases adequate food supplies are available if properly used. One example that illustrates how increased crop yields can contribute to increased populations will be given for U.S. maize production (Table 2). Population of the United States increased from approximately 90 million citizens in 1900 to more than 303 million in 2010, i.e., population increased 3.37 times. During the same time-frame, average U.S. maize yields have increased from 1.71 tons ha ${ }^{-1}$ (27.4 bu acre ${ }^{-1}$ ) for 1901-1910 to 9.31 tons ha-1 (148.9 bu acre be $\left.^{-1}\right)$ for 2001-2010; i.e., average U.S. maize yields have increased
5.47 times compared with a population increase of 3.37 during the 110-year span (Table 2). Several factors have contributed to the increased grain yields. Duvick (2005), for example, reported that 50 to $60 \%$ of the increased U.S. grain yields were because of improved genetics of the cultivars; similar results of 2.6 to $2.9 \%$ gain per year have been reported in other maize production areas (Tollenaar 1989, Eyerhabide and Damilano 2001, Wang et al. 2011). Optimistically, it seems further genetic progress can be sustained because as greater genetic information at the molecular level is understood and integrated with phenotypic selection, it will increase our effectiveness of selection. It will be essential that increased crop yields on a per unit area be continued in the future.

The human and financial resource allocated to plant breeding research has had significant changes during the last half of the $20^{\text {th }}$ century (Frey 1996). With the rediscovery of Mendelian genetics in 1900, publicly supported researchers were in the forefront conducting basic research on the inheritance of traits and application of this information for cultivar development. By year 2000, significant changes in human and financial resources for plant breeding had been transposed from primarily the public sector to the private sector. Interest in the commercial potential of products derived from molecular studies delivered in plant cultivars dramatically increased the interests of private enterprise. Hence, private support for plant breeding increased very rapidly. By contrast resources dedicated to plant breeding in the public sector either significantly decreased or were transferred to the study of molecular genetics. This dichotomy of resources for public and private research has transposed during the $20^{\text {th }}$ century because of the advances made in genetics and their value commercially. It seems this trend will continue in the future. The competitive nature of private enterprises will ensure that resources are made available to compete in the marketplace. Although the level of financial resources allocated to plant breeding has rapidly increased during the past 30 years, the investments have had favorable returns (Crosbie et al. 2006). Rapid progress also has been made in many nongenetic areas, such as plot equipment, computer systems for recording field data, field designs, statistical analyses, defining target environments, etc, have contributed significantly to increasing the efficiency of plant and progeny selection, or determining the breeding values for data taken at the phenotypic level (Hallauer and Pandey 2006). Based on the past successes of plant breeders, it is my opinion that plant breeders will continue 
Table 2. Relative changes in maize production and human populations in the United States from 1901 to 2010

\begin{tabular}{|c|c|c|c|c|}
\hline Years & $\begin{array}{l}\text { Acreage harvested } \\
\text { (ha } x \text { 1000) }\end{array}$ & $\begin{array}{c}\text { Yield } \\
\left(\mathrm{t} \mathrm{ha}^{-1}\right)\end{array}$ & $\begin{array}{l}\text { Total produced } \\
\qquad(t \times 1000)\end{array}$ & $\begin{array}{l}\text { U. S. Population } \\
\text { (x 1000) }\end{array}$ \\
\hline $1901-1910$ & 39,077 & 1.70 & $65,807.4$ & 2010: 90,000 \\
\hline $2001-2010$ & 30,530 & 9.31 & 281.684 .5 & 2010: 203,000 \\
\hline Changes & $-21.87 \%$ & x 5.48 & $\mathrm{x} 4.28$ & x 3.37 \\
\hline \multicolumn{5}{|l|}{2010} \\
\hline Winners $(\mathrm{n}=15)^{+}$ & & 18.04 & & \\
\hline Average USA & & 9.55 & & \\
\hline
\end{tabular}

+ Winners for 2010 National Corn Growers Association Maize Contests conducted throughout the United States.

to have an important role to provide adequate and good quality field cultivars to meet our future needs. Because greater genetic information has become available the art vs science of plant breeding has increased the relative importance to science. But, the phenotypes of the newer cultivars developed with greater emphasis on science will remain an important component of plant breeding.
The great $17^{\text {th }}$ century French philosopher Rene Descartes made an interesting observation that applies to plant breeding: "emphasis on the application of scientific principles to practical everyday use."

\section{Evolução do melhoramento de plantas}

RESUMO - Melhoramento de plantas é considerado uma das mais longas atividades contínuas realizadas por humanos, os quais selecionam plantas mais produtivas e úteis às necessidades próprias e animais, há pelo menos 10.000 anos atrás. A evolução das civilizações ocorreu em paralelo com o sucesso do melhoramento, embora este não tenha recebido o devido reconhecimento do público. A razão talvez seja a falta de entendimento do que seja o melhoramento. O próprio conceito de melhoramento evoluiu, dependendo do tempo em que foi formulado, sem, contudo, perder a essência de ser a arte e a ciência de manipular plantas em favor do homem. Nessa revisão é discutida a evolução do conceito de melhoramento e dos seus métodos, aqui divididos arbitrariamente em seleção baseada em fenótipos, valores de melhoramento e genótipos. Por maior que seja o acervo de informações genéticas dos últimos anos, o fenótipo continuará a ser importante no presente e no futuro.

Palavras-chave: conceitos de melhoramento; fenótipos; valor genético; genótipos.

\section{REFERENCES}

Abreu GB, Ramalho MAP, Toledo FHR and Souza JC (2010) Strategies to improve mass selection in maize. Maydica 55: 219-22.5.

Bauman LF (1981) Review of methods used by breeders to develop superior corn inbreds. In $36^{\text {th }}$ Annual corn sorghum industry research conference, pp. 199-2008.

Bernardo R (2002) Breeding for quantitative traits. Stemma Press, Minneapolis, 400p.

Briggs FN and Knowles PF (1967) Introduction to plant breeding. Reinhold, San Francisco, 426p.

Coons GH (1936) Improvement of the sugar beet. In Yearbook of agriculture. USDA, U.S. Government Printing Office, Washington, D. C., p. 625-651.
Coors JG and Pandey S (1999) The genetics and exploitation of heterosis in crops. American society of agronomy and crop science, Madison, 524p.

Crosbie TM, Eathington SR, Johnson GR, Edwards M, Reiter R, Stark S, Mohanty RG, Oyerdes M, Buehler RE, Walker AK, Dobert R, Delannay X, Pershing JC, Hall MA and Lamkey KR (2006) Plant breeding: past, present and future. In Lamkey KR and Lee M (eds). Plant breeding: the Arnel R. Hallauer international symposium. Blackwell Publishing, Ames, p. 350 .

Darwin CR (1859) The origin of species. Harvard University Press, 513p.

Dunn LC (1965) Mendel, his work and his place in history. In 109 Proceedings of the American philosophical society, p. 189-198 
AR Hallauer

Duvick DN (2004) Long-term selection in a commercial breeding program. In Janick J (ed.) Plant breeding review 24, Part 2. John Wiley \& Sons, Hoboken, p. 109-151.

Duvick DN (2005) The contribution of breeding to yield advances in maize (Zea mays L.). Advanced Agronomy 86: 83-145.

Eyerhabide GH and Damilano AL (2001) Comparison of genetic gain for grain yield of maize between the 1980's and 1990's in Argentina. Maydica 46: 277-281.

Falconer D (1960) Introduction to quantitative genetics. Oliver and Boyd, Edinburgh, 365p.

Fisher RA (1918) The correlation between relatives on the supposition of Mendelian inheritance. Transactions of the Royal Society of Edinburgh 52: 399-433.

Fisher RA (1925) Statistical methods for research workers. Oliver and Boyd, Edinburgh, 239p.

Frankel OH (1958) The dynamics of plant breeding. Journal of Australian Institute of Agriculture Science 24: 112.

Frey KJ (1966) Plant Breeding. Iowa State University Press, Ames,300p.

Frey KJ (1996) National plant breeding study - 1. Iowa State University, Ames, 30p. (Iowa State University Special Report 98)

Gardner CO (1961) An evaluation of effects of mass selection and seed irradiation with thermal neutrons on yield of corn. Crop Science 1: 241-245.

Gepts P (2002) A comparison between crop domestication, classical plant breeding, and genetic engineering. Crop Science 42: 1780-1790.

Hallauer AR (2001) Specialty corns. CRC Press, Boca Raton, $479 \mathrm{p}$.

Hallauer AR and Carena MJ (2009) Maize breeding. In Carena MJ (ed) Cereals. Springer-Verlag, New York, p. 3-98

Hallauer AR and Pandey S (2006) Defining and achieving plant breeding goals. In Lamkey KR and Lee M (eds). Plant breeding: the Arnel R. Hallauer international symposium. Blackwell Publishing, Ames, p. 73-89.

Hallauer AR, Miranda Filho JB and Carena MJ (2010) Quantitative genetics in maize breeding. Springer, New York, 663p.

Johnson GR (2004) Marker-assisted selection. In Janick J (ed) Plant breeding review 24 - Part 1. John Wiley \& Sons, Hoboken, p. 293-309.

Hopkins G (1899) Improvements in the chemical composition of the corn kernel. Illinois Agriculture Experimental Station Bulletin 55: 205-240.
Lee M (2006) The phenotypic and genotypic eras of plant breeding. In Lamkey KR and Lee M (eds) Plant breeding: the Arnel R. Hallauer international symposium. Blackwell Publishing, Ames, p. 213-218.

Lonnquist JH (1964) A modification of the ear-to-row procedure for the improvement of maize populations. Crop Science 4: 227-228.

Marquez-Sanchez F (2010) A proposal to long term response to maize mass selection. Maydica 55: 135-137.

Pixley KV (2006) Hybrid and open-pollinated varieties in modern agriculture. In Lamkey KR and Lee M (eds) Plant breeding: the Arnel R. Hallauer international symposium. Blackwell, Ames, p. 234-250.

Poehlman JM and Sleper DA (1995) Breeding field crops. Iowa State University Press, Ames, 417p.

Provine WB (1971) The origins of theoretical population genetics. The University of Chicago Press, Chicago, 207p.

Shull GH (1910) Hybridization methods in corn breeding. American Breeders Association Report 6: 98-107.

Stoskopf NC, Tomes DT and Christie BR (1993) Plant breeding: theory and practice. Westview Press, Boulder, 300p.

Sturtevant EL (1899) Varieties of corn. USDA Office Experimental Station, 19p. (Bulletin 57).

Tollenaar M (1989) Genetic improvement in grain yield of commercial maize hybrids grown in Ontario from 1959 to 1988. Crop Science 29: 1365-1371.

Tracy WF and Chandler MA (2006) The historical and biological basis of the concept of heterotic patterns in Corn Belt dent maize. In Lamkey KR and Lee M (eds) Plant breeding: the Arnel R. Hallauer international symposium. Blackwell, Ames, p. 219-233.

Vassel SK (2001) High quality protein corn. In Hallauer AR (ed) Specialty corns. CRC Press, Boca Raton, p. 85-129

Vavilov NI (1935) The origin, variation, immunity and breeding of cultivated plants. Translated by K. Staer Chester 1851. Ronald Press, New York.

Wang T, Ma X, Li Y, Bai D, Liu C, Liu Z, Tan X, Shi Y, Song Y, Carlone M, Bubeck D, Bhardwaj H, Jones E, Wright K and Smith S (2011) Changes in yield and yield components of singlecross hybrids released in China between 1964 and 2001. Crop Science 51: 512-525.

Watson JD and Crick FHC (1953) The structure of DNA ring. Harbor Symposium. Quantitative Biology 23: 123-131.

Williams W (1964) Genetic principles and plant breeding. Blackwell, Oxford. 